\title{
Diallel Among Soybean Genotypes with High Oil Content and Resistance to Sudden Death Syndrome
}

\author{
Inocencio Junior de Oliveira ${ }^{1 *}$, Natal Antonio Vello ${ }^{2}$, Paulo de Melo Jorge Vieira ${ }^{3}$ and \\ Philip Traldi Wyminersky ${ }^{2}$ \\ ${ }^{1}$ Embrapa Amazônia Ocidental; Manaus - AM - Brasil. ${ }^{2}$ Escola Superior de Agricultura Luiz de Queiroz; \\ Universidade de São Paulo; Piracicaba - SP - Brasil. ${ }^{3}$ Embrapa Meio-Norte; Teresina - PI - Brasil
}

\begin{abstract}
The objective of this work was to use a partial diallel to evaluate the combining ability of 14 soybean genotypes and recommend superior combinations. Seven of the genotypes had high oil yield; other seven exhibited tolerance to sudden death syndrome and they generated 49 hybrids in a diallel cross without reciprocals. $F_{2}$ plants of each cross and the parents were evaluated for the following traits: number of days to maturity (NDM), oil content in the seeds $(O C)$, grain yield $(G Y)$ and oil yield $(O Y)$. The results indicated the existence of genetic variability in the parents and progeny for all the traits. The rank of the parents based on the means was similar to the rank based on general combining ability (GCA) for all the traits. The specific combining ability (SCA) and the GCA were significant for all the traits, with a predominance of additive effects. The parent with the highest GCA and mean for OC was the cultivar A 7002; on the other hand, the lowest values were found in PI 520733 and IAC 100. The crosses with the highest oil yields were those involving parent A 7002, except when it was crossed with IAC 100.
\end{abstract}

Key words: Glycine max, combining ability, oil yield, tolerance

\section{INTRODUCTION}

Soybean is the oilseed crop that occupies the largest area in the world and represents $60 \%$ of oilseed production (Sudaric et al. 2008). It is one of the main sources of vegetable oil. Brazil has the large diversity and yield of crops that can be used to produce vegetable oil, opening a unique opportunity for a new energy alternative, biofuels. Of the five top cultures with the huge potential for the production of biodiesel (oil palm, canola, castor bean, peanut and soybean), in the short term, soybean presents the best perspective, because it yields an average 0.6 t.ha $^{-1}$ of oil (in a four month period) and because it already has logistic, industrial, storage and distribution networks in place. Furthermore, another product extracted in the process of crushing the grain is the meal, the main source of protein for animal feed (Brieu and Parente 2009).

In the germplasm banks, the phenotypic variability is large for oil content, from 6 to $27 \%$. Brazilian cultivars have the seeds with oil content of 18 to $25 \%$ with an average of $20 \%$. Therefore, it is possible to obtain, through crosses and selection, new soybean genotypes with higher oil content in the seeds. Farias Neto and Vello (2001) reported that the predominance of genetic additive variance indicated the possibility of obtaining transgressive segregants for oil content.

Sudden death syndrome (SDS), caused by Fusarium solani f. sp. glycines, is a root disease that, despite being present in some areas of Brazil since the 1980's, has only started to cause serious

*Author for correspondence: inocencio.oliveira@embrapa.br 
losses in the 1990's. Therefore, the use of resistant cultivars is a fundamental component in the integrated management of SDS. Due to the probable polygenic nature of genetic resistance to this disease and the large environmental influence in the manifestation of symptoms, coupled with the fact that there are no efficient chemical or cultural methods of control, SDS has become a major concern to soybean farmers and researchers in the regions where it occurs (Fronza et al. 2004). Because of the demand from the oil-chemistry industry and, recently, with the possibility of using soybean oil as a biofuel, it has become fundamental to develop new genetic material with a higher oil yield and also tolerance to the main root diseases. One recommended strategy is the adoption of an integrated management system in which the utilization of resistant/tolerant cultivars is an indispensable component. Therefore, the objective of this work was to evaluate through a partial diallel the combining ability of 14 soybean parents and their superior combinations.

\section{MATERIALS AND METHODS}

Between December 2007 and February 2008 biparental crosses were performed between the seven parents with SDS tolerance (group 1 or $\mathrm{G}_{1}$ ) and the seven parents with high oil yield (group 2 or $\mathrm{G}_{2}$ ), selected based on the evaluations in greenhouse and field trials in the 2005/2006 and 2006/2007 seasons by the Sector of Applied Genetics to Autogamous Species, Department of Genetics, ESALQ/USP, in Piracicaba - SP. It was designed as a partial diallel with a total of 49 crosses, which were conducted in the greenhouse.

After obtaining the $F_{2}$ seeds from the partial diallel, these were sown in November 2008 for the 2008/2009 season in hills with a spacing of $0.8 \mathrm{~m}$ x $0.8 \mathrm{~m}$. Each plot was composed of 12 hills, with each hill having up to six seeds, followed by thinning, leaving one plant per hill, which consisted of the SHDT method (Single Hill Descent Thinned) proposed by Vello (1992). The parents used are shown in Table 1.

Table 1 - Parents used in the partial diallel between seven genotypes with SDS tolerance and seven genotypes with high oil yield.

\begin{tabular}{|c|c|c|c|}
\hline Parents tolerant to SDS & Genealogies & High oil yield parents & Genealogies \\
\hline 1- USP $14-10-38^{\mathrm{a}}$ & Conquista $\mathrm{x}$ FT-Estrela & 8- USP $70.006^{\mathrm{a}}$ & Foster x FT 79-3408 \\
\hline 2- USP $14-01-20^{\mathrm{a}}$ & FT-Cristalina $\mathrm{x}$ IAC-4 & 9- USP $70.057^{\mathrm{a}}$ & x FT-2 \\
\hline 3- USP $14-07-05^{\mathrm{a}}$ & IAC-4 x FT-Estrela & 10- USP $70.004^{\mathrm{a}}$ & 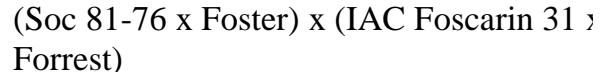 \\
\hline 4- US & FT-Estrela x Forrest & 11- USP $70.109^{\mathrm{a}}$ & (IAC-6 x UFV-4) x Hartwig \\
\hline 5- PI 520733 ${ }^{\mathrm{b}}$ & & 12- USP $70.080^{\mathrm{a}}$ & $\mathrm{x}$ Primavera) $\mathrm{x}$ (Viçoja $\mathrm{x}$ IAC-10 \\
\hline 6- IAC 100 & IAC 78-2318 x IAC 12 & 13- A 7002 & Suprema x F92-1473 \\
\hline 7- M-Soy 8001 & - & 14- USP $70.123^{\mathrm{a}}$ & $\begin{array}{l}\text { (Paranagoiana x Jackson 4028) x } \\
\text { (Primavera x Forrest) }\end{array}$ \\
\hline
\end{tabular}

${ }^{\mathrm{a}}$ Experimental lines developed by the Sector of Applied Genetics to Autogamous Species, Department of Genetics, ESALQ, USP. ${ }^{\mathrm{b}}$ Genotypes described in GRIN (Germplasm Resources Information Network) as moderately resistant to SDS.

The experimental design was randomized complete-blocks with six replications. Each cross was represented by $72 F_{2}$ plants. Sixty-three genotypes were evaluated, consisting of 49 crosses and 14 parents. Due to the extent of the blocks, each was subdivided into three experimental sets. Each set had 21 genotypes and three common checks: MG/BR-46 Conquista (Conquista), FMTTucunaré and UFVS 2002. The common checks allowed the evaluation of block uniformity and, if necessary, to adjust the means and the effective error mean square, according to Federer (1956). The evaluated traits were: the number of day to maturity (NDM), which comprehended the period between the planting and the date when the plants reached the $\mathrm{R}_{8}$ stage; grain yield (GY) in g.plant ${ }^{-1}$, evaluated at maturity; oil content in the seed (\% OC), which was evaluated using the nuclear magnetic resonance (NMR) (the evaluation of oil content in $\mathrm{F}_{3}$ seeds was interpreted as being correspondent to $F_{2}$ plant performance due to the nuclear maternal inheritance of the character, Miranda et al. 1984); oil yield (OY) in g.plant ${ }^{-1}$, obtained as the product of grain yield and oil content in the seeds divided by $100\left(\mathrm{~g} \mathrm{plant}^{-1}\right)$. The analyses of the data were carried out using the SAS® computer package (Statistical Analysis System) (SAS Institute Inc 1999) and also the 
GENES computer package (Cruz 2006). With the means adjusted, if necessary, the analyses of variance were performed according to the randomized complete-block design with more than one plant evaluated per plot (Ramalho et al. 2005). The statistical procedures adopted for the analyses of variance also involved the unfolding of the genotype source of variation into the parents, crosses and the parent vs. crosses contrast.

From the means obtained for all the traits, a diallel analysis was performed according to model 2 (Griffing 1956), involving the parents and $F_{1}$ 's without reciprocals (Geraldi and Miranda Filho 1988) for a partial diallel in which the general combining ability (GCA) and specific combining ability (SCA) were estimated to predict the potential and combining ability of the crosses. The comparison of means was made through the means grouping by the Scott and Knott (1974) method.

\section{RESULTS AND DISCUSSION}

An analysis of variance was performed to verify the check effects in the proposed design. The purpose of adjusting using common checks is to reduce the residual standard deviation and increase the experimental precision (Pimentel Gomes 2000). The source of variation sets was significant $(\mathrm{p}<0.01$ and $\mathrm{p}<0.05)$ for the NDM and GY traits, respectively. Therefore, it was necessary to adjust the means through an environmental correction for those traits. After adjusting the data, an analysis of variance was performed in randomized completeblock design with the information within the plot of $\mathrm{F}_{2}$ plants and parents, evaluated in hills (Table 2). The coefficients of variation were 1.9, 12.5, 2.7 and $14.2 \%$ for the traits NDM, GY, OC and OY, respectively, and were similar to those in the literature (Lopes et al. 2002 and Vieira 2009). They were adequate for an experiment with hills, showing good experimental precision (Pimentel Gomes 2000).

Table 2 - Analysis of variance of $\mathrm{F}_{2}$ plants (crosses) and parents, in hills, for the traits number of days to maturity (NDM), grain yield (GY), oil content (OC) and oil yield (OY). Soybean, ESALQ, Piracicaba-SP, Year 2008/2009.

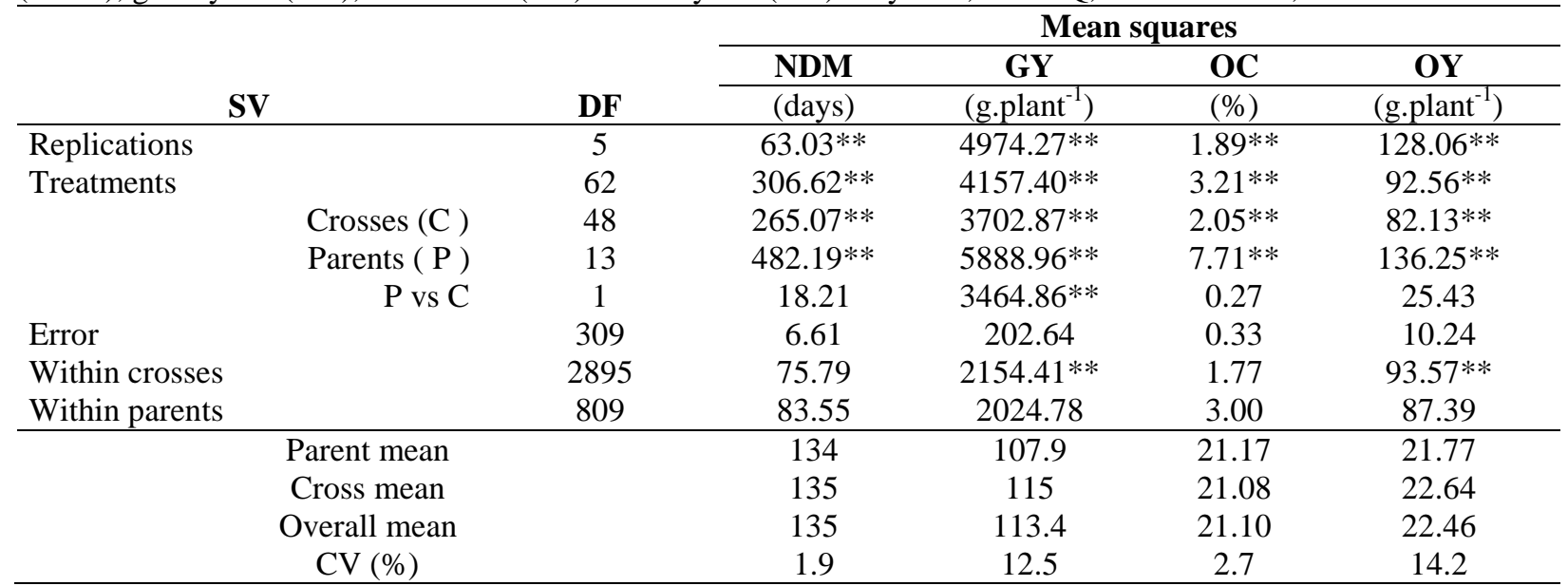

Notes: * and $* *$ significant at 5 and $1 \%$ probability, respectively, for the $\mathrm{F}$ test.

The sources of variation parents $(\mathrm{P})$ and crosses (C) between the plots were significant $(\mathrm{p}<0.01)$, using the $\mathrm{F}$ test for all the traits evaluated, showing variability in the parents and crosses. The contrast $\mathrm{P}$ vs. C was significant only for the GY trait, with crosses being superior to parents, having a higher mean. With this, it was possible to obtain progenies that were superior to the parents, transgressive genotypes. Lopes et al. (2002) also reported that $\mathrm{F}_{2}$ plants were more productive than the parents while evaluating soybean genotypes in the Anhembi Experimental Station, which also belonged to ESALQ. Table 3 presents the comparison of the means of the parents and crosses with the Scott-Knott test in the $F_{2}$ generation for all the traits evaluated.

In relation to the NDM trait in group 1, the earliest maturing parent in the whole experiment was PI 520.733 (5). PI's usually did not have the same adaptation as selected genotypes indicated for the region. 
Table 3 - Comparison of means in the $\mathrm{F}_{2}$ generation, in hills, for the traits number of days to maturity (NDM), grain yield (GY), oil content (OC) and oil yield (OY). Soybean, ESALQ, Piracicaba-SP, Year 2008/2009.

\begin{tabular}{|c|c|c|c|c|}
\hline Crosses & NDM (days) & GY (g.plant ${ }^{-1}$ ) & $\mathrm{OC}(\%)$ & OY (g.plant ${ }^{-1}$ ) \\
\hline $1 \times 8$ & $140 \mathrm{~b}$ & $114 \mathrm{c}$ & $20.70 \mathrm{c}$ & $19.70 \mathrm{c}$ \\
\hline $1 \times 9$ & $133 \mathrm{~d}$ & $115 \mathrm{c}$ & $21.75 \mathrm{~b}$ & $21.97 \mathrm{~b}$ \\
\hline $1 \times 10$ & $136 \mathrm{c}$ & $121 \mathrm{~b}$ & $21.19 \mathrm{c}$ & $24.38 \mathrm{~b}$ \\
\hline $1 \times 11$ & $135 \mathrm{c}$ & $130 \mathrm{~b}$ & $21.17 \mathrm{c}$ & $24.56 \mathrm{~b}$ \\
\hline $1 \times 12$ & $136 \mathrm{c}$ & $151 \mathrm{a}$ & $21.35 \mathrm{c}$ & $31.87 \mathrm{a}$ \\
\hline $1 \times 13$ & $142 \mathrm{a}$ & $133 \mathrm{~b}$ & $22.02 \mathrm{~b}$ & $26.33 \mathrm{~b}$ \\
\hline $1 \times 14$ & $139 \mathrm{~b}$ & $126 \mathrm{~b}$ & $20.94 \mathrm{c}$ & $22.99 \mathrm{~b}$ \\
\hline $2 \times 8$ & $141 \mathrm{a}$ & $131 \mathrm{~b}$ & $21.52 \mathrm{c}$ & $23.53 \mathrm{~b}$ \\
\hline $2 \times 9$ & $135 \mathrm{c}$ & $110 \mathrm{c}$ & $21.49 \mathrm{c}$ & $21.75 \mathrm{~b}$ \\
\hline $2 \times 10$ & $135 \mathrm{c}$ & $123 \mathrm{~b}$ & $21.45 \mathrm{c}$ & $23.96 \mathrm{~b}$ \\
\hline $2 \times 11$ & $133 \mathrm{~d}$ & $142 \mathrm{a}$ & $21.53 \mathrm{c}$ & $29.66 \mathrm{a}$ \\
\hline $2 \times 12$ & $136 \mathrm{c}$ & $162 \mathrm{a}$ & $21.64 \mathrm{c}$ & $33.21 \mathrm{a}$ \\
\hline $2 \times 13$ & $140 \mathrm{~b}$ & $142 \mathrm{a}$ & $22.20 \mathrm{~b}$ & $28.55 \mathrm{a}$ \\
\hline $2 \times 14$ & $140 \mathrm{~b}$ & $134 \mathrm{~b}$ & $21.15 \mathrm{c}$ & $26.05 \mathrm{~b}$ \\
\hline $3 \times 8$ & $140 \mathrm{~b}$ & $128 \mathrm{~b}$ & $20.53 \mathrm{c}$ & $23.76 \mathrm{~b}$ \\
\hline $3 \times 9$ & $136 \mathrm{c}$ & $104 \mathrm{c}$ & $21.67 \mathrm{c}$ & $20.01 \mathrm{c}$ \\
\hline $3 \times 10$ & $136 \mathrm{c}$ & $115 \mathrm{c}$ & $21.41 \mathrm{c}$ & $18.96 \mathrm{c}$ \\
\hline $3 \times 11$ & $136 \mathrm{c}$ & $137 \mathrm{~b}$ & $21.54 \mathrm{c}$ & $25.27 \mathrm{~b}$ \\
\hline $3 \times 12$ & $137 \mathrm{c}$ & $146 \mathrm{a}$ & $22.17 \mathrm{~b}$ & $29.54 \mathrm{a}$ \\
\hline $3 \times 13$ & $141 \mathrm{a}$ & $122 \mathrm{~b}$ & $22.42 \mathrm{~b}$ & $24.20 \mathrm{~b}$ \\
\hline $3 \times 14$ & $142 \mathrm{a}$ & $141 \mathrm{a}$ & $21.55 \mathrm{c}$ & $27.12 \mathrm{a}$ \\
\hline $4 \times 8$ & $140 \mathrm{~b}$ & $123 \mathrm{~b}$ & $21.21 \mathrm{c}$ & $24.70 \mathrm{~b}$ \\
\hline $4 \times 9$ & $137 \mathrm{c}$ & $103 \mathrm{c}$ & $21.09 \mathrm{c}$ & $18.35 \mathrm{c}$ \\
\hline $4 \times 10$ & $137 \mathrm{c}$ & $108 \mathrm{c}$ & $21.20 \mathrm{c}$ & $20.96 \mathrm{c}$ \\
\hline $4 \times 11$ & $132 \mathrm{~d}$ & $109 \mathrm{c}$ & $21.33 \mathrm{c}$ & $19.19 \mathrm{c}$ \\
\hline $4 \times 12$ & $134 \mathrm{~d}$ & $125 \mathrm{~b}$ & $21.46 \mathrm{c}$ & $25.85 \mathrm{~b}$ \\
\hline $4 \times 13$ & $142 \mathrm{a}$ & $136 \mathrm{~b}$ & $22.24 \mathrm{~b}$ & $30.36 \mathrm{a}$ \\
\hline $4 \times 14$ & $140 \mathrm{~b}$ & $130 \mathrm{~b}$ & $21.37 \mathrm{c}$ & $26.50 \mathrm{~b}$ \\
\hline $5 \times 8$ & $122 \mathrm{e}$ & $55 \mathrm{e}$ & $19.58 \mathrm{~d}$ & $11.24 \mathrm{~d}$ \\
\hline $5 \times 9$ & $119 \mathrm{f}$ & $47 \mathrm{e}$ & $20.83 \mathrm{c}$ & $8.19 \mathrm{~d}$ \\
\hline $5 \times 10$ & $119 \mathrm{f}$ & $55 \mathrm{e}$ & $20.45 c$ & $14.00 \mathrm{~d}$ \\
\hline $5 \times 11$ & $121 \mathrm{e}$ & $73 \mathrm{~d}$ & $21.10 \mathrm{c}$ & $15.56 \mathrm{c}$ \\
\hline $5 \times 12$ & $119 \mathrm{f}$ & $87 \mathrm{~d}$ & $20.45 c$ & $17.03 \mathrm{c}$ \\
\hline $5 \times 13$ & $123 \mathrm{e}$ & $91 \mathrm{~d}$ & $21.99 \mathrm{~b}$ & $20.54 \mathrm{c}$ \\
\hline $5 \times 14$ & $118 \mathrm{f}$ & 59 e & $19.29 \mathrm{~d}$ & $12.05 \mathrm{~d}$ \\
\hline $6 \times 8$ & $139 \mathrm{~b}$ & $107 \mathrm{c}$ & $19.04 \mathrm{~d}$ & $19.88 \mathrm{c}$ \\
\hline $6 \times 9$ & $133 \mathrm{~d}$ & $96 \mathrm{c}$ & $19.62 \mathrm{~d}$ & $17.24 \mathrm{c}$ \\
\hline $6 \times 10$ & $133 \mathrm{~d}$ & $96 \mathrm{c}$ & $19.58 \mathrm{~d}$ & $18.31 \mathrm{c}$ \\
\hline $6 \times 11$ & $134 \mathrm{~d}$ & $103 \mathrm{c}$ & $20.05 \mathrm{~d}$ & $18.83 \mathrm{c}$ \\
\hline $6 \times 12$ & $133 \mathrm{~d}$ & $119 \mathrm{c}$ & $19.45 \mathrm{~d}$ & $23.44 \mathrm{~b}$ \\
\hline $6 \times 13$ & $139 \mathrm{~b}$ & $128 \mathrm{~b}$ & $20.75 \mathrm{c}$ & $25.57 \mathrm{~b}$ \\
\hline $6 \times 14$ & $137 \mathrm{c}$ & $108 \mathrm{c}$ & $19.77 \mathrm{~d}$ & $21.03 \mathrm{c}$ \\
\hline $7 \times 8$ & $136 \mathrm{c}$ & $122 \mathrm{~b}$ & $21.19 \mathrm{c}$ & $23.23 \mathrm{~b}$ \\
\hline $7 \times 9$ & $139 \mathrm{~b}$ & $103 \mathrm{c}$ & $20.74 c$ & $20.74 c$ \\
\hline $7 \times 10$ & $136 \mathrm{c}$ & $124 \mathrm{~b}$ & $21.48 \mathrm{c}$ & $27.53 \mathrm{a}$ \\
\hline $7 \times 11$ & $135 \mathrm{c}$ & $113 \mathrm{c}$ & $21.23 \mathrm{c}$ & $22.52 \mathrm{~b}$ \\
\hline $7 \times 12$ & $135 \mathrm{c}$ & $135 \mathrm{~b}$ & $21.31 \mathrm{c}$ & $27.38 \mathrm{a}$ \\
\hline $7 \times 13$ & $143 \mathrm{a}$ & $133 \mathrm{~b}$ & $22.33 \mathrm{~b}$ & $27.24 \mathrm{a}$ \\
\hline $7 \times 14$ & $137 \mathrm{c}$ & $121 \mathrm{~b}$ & $21.16 \mathrm{c}$ & $24.74 \mathrm{~b}$ \\
\hline \multicolumn{5}{|l|}{ Parents } \\
\hline 1 - USP 14-10-38 & $138 \mathrm{~b}$ & $108 \mathrm{c}$ & $20.78 \mathrm{c}$ & $21.60 \mathrm{~b}$ \\
\hline 2 - USP 14-01-20 & $142 \mathrm{a}$ & $142 \mathrm{a}$ & $21.53 \mathrm{c}$ & $28.51 \mathrm{a}$ \\
\hline 3 - USP 14-07-05 & $143 \mathrm{a}$ & $117 \mathrm{c}$ & $21.31 \mathrm{c}$ & $23.66 \mathrm{~b}$ \\
\hline 4 - USP 14-13-16 & $139 \mathrm{~b}$ & $111 \mathrm{c}$ & $20.93 \mathrm{c}$ & $21.80 \mathrm{~b}$ \\
\hline 5 - PI 520.733 & $110 \mathrm{~g}$ & $16 \mathrm{f}$ & $17.66 \mathrm{e}$ & $2.62 \mathrm{e}$ \\
\hline 6 - IAC 100 & $134 \mathrm{~d}$ & $115 \mathrm{c}$ & $17.99 \mathrm{e}$ & $17.81 \mathrm{c}$ \\
\hline 7 - M-SOY 8001 & $138 \mathrm{~b}$ & $125 \mathrm{~b}$ & $21.29 \mathrm{c}$ & $25.15 \mathrm{~b}$ \\
\hline 8 - USP 70.006 & $138 \mathrm{~b}$ & $109 \mathrm{c}$ & $21.76 \mathrm{~b}$ & $21.01 \mathrm{c}$ \\
\hline 9 - USP 70.057 & $130 \mathrm{~d}$ & $86 \mathrm{~d}$ & $21.81 \mathrm{~b}$ & $16.95 \mathrm{c}$ \\
\hline 10 - USP 70.004 & $123 \mathrm{e}$ & $101 \mathrm{c}$ & $22.34 \mathrm{~b}$ & $20.94 \mathrm{c}$ \\
\hline 11 - USP 70.109 & $130 \mathrm{~d}$ & $100 \mathrm{c}$ & $22.09 \mathrm{~b}$ & $21.93 \mathrm{~b}$ \\
\hline 12 - USP 70.080 & $134 \mathrm{~d}$ & $151 \mathrm{a}$ & $21.52 \mathrm{c}$ & $31.31 \mathrm{a}$ \\
\hline 13 - A 7002 & $145 \mathrm{a}$ & $104 \mathrm{c}$ & $23.90 \mathrm{a}$ & $25.68 \mathrm{~b}$ \\
\hline 14 - USP 70.123 & $136 \mathrm{c}$ & $125 \mathrm{~b}$ & $21.42 \mathrm{c}$ & $25.86 \mathrm{~b}$ \\
\hline
\end{tabular}

Means followed by the same letter in the columns do not differ statistically from each other by the Scott-Knott test at $5 \%$ probability. 
In this study, this PI was statistically different, through the Scott-Knott test at 5\% probability, from all the other parents and crosses and was grouped separately. In group 2 , the earliest maturing parent was the line USP 70004 (10), which presented the same mean as the crosses between PI 520.733 (5) with the genotypes USP 70006 (8), USP 70109 (11) and A 7002 (13). The earliest maturing crosses were the ones that involved PI 520.733 (5) with the lines USP 70123 (14), USP 70057 (9), USP 70004 (10) and USP 70080 (12). The late maturing parents were A 7002 (13) from group 2 and USP 14-07-05 (3) and USP 14-01-20 (2) from group 1; they did not statistically differ from each other and did not also differ from the crosses USP 14-07-05 (3) X USP 70123 (14), USP 14-01-20 (2) X USP 70006 (8) and the crosses of cultivar A 7002 (13) with the genotypes M-Soy 8001 (7), USP 14-13-16 (4), USP 14-10-38 (1) and USP 14-07-05 (3). In general, crosses with the PI generated early maturing progenies, while crosses with the parent A 7002 (13) originated late maturing progenies, with exception to its cross with the PI.

For the traits GY and OY, the parents with the highest values per se were USP 14-01-20 (2) (group 1) and USP 70080 (12) (group 2). The crosses that stood out for these traits, but did not statistically differ from these parents were the crosses that involved the USP 14-01-20 (2) with the genotypes USP 70080 (12), USP 70109 (11) and A 7002 (13); the line USP 70080 (12) with USP 14-10-38 (1) and USP 14-07-05 (3); and the cross USP 70123 (14) x USP 14-07-05 (3). This last one could be an indicator of a good specific combining ability. The parent with the lowest mean for GY and OY was PI 520.733 (5), which statistically differsed from all the other parents and crosses. The crosses with the lowest means also involved PI 520.733 (5) with the lines USP 70057 (9), USP 70006 (8) and USP 70123 (14). Some crosses such as USP 14-13-16 (4) x A 7002 (13), M-Soy 8001 (7) x USP 70004 (10), M-Soy 8001 (7) x USP 70080 (12) and M-Soy 8001 (7) x A 7002 (13) stood out because they were present in the grouping with the highest means for OY but not for GY. This was due to high oil contents in these crosses.

The trait OC, the parents from group 2, selected for the diallel, which possessed the genes for high oil content, had the highest means, with the exception of parents USP 70080 (12) and USP 70123 (14). Parent A 7002 (13) had the highest mean $(23.90 \%)$ and was statistically different from all the parents and crosses. The parents with the lowest means for OC were PI 520.733 (5) with $17.66 \%$ and IAC 100 (6) with $17.99 \%$. The crosses with the highest mean values for OC were those that involved parent A 7002 (13), except when it was crossed to IAC 100 (6), and the cross USP 1407-05 (3) x USP 70080 (12). The crosses with the lowest means were those that involved parent IAC 100 (6), except when it was crossed to cultivar A 7002 (13), and also the crosses PI 520.733 (5) $\mathrm{x}$ USP 70123 (14) and PI 520.733 (5) x USP 70006 (8).

Table 4 shows the analysis of variance of the partial diallel for all the traits evaluated. It was concluded that the additive variance, expressed by the mean squares of the GCA, was comparatively higher than the non-additive variance. However, the non-additive effects and the additive effects manifest between the parents in groups 1 and 2 were also significant. The GCA is of great importance to the breeders that work with autogamous plants because if there is additive variance, it will contribute to selection progress and will be present in subsequent generations.

Table 4 - Analysis of variance for the partial diallel of the parents from groups 1 and 2 and their hybrid combinations for the traits number of days to maturity (NDM), grain yield (GY), oil content (OC) and oil yield (OY) using the Griffing (1956) mehtod adapted for a partial diallel. Soybean, ESALQ, Piracicaba-SP, Year 2008/2009.

\begin{tabular}{|c|c|c|c|c|c|}
\hline & & & Mear & ares & \\
\hline & & NDM & GY & OC & OY \\
\hline SV & DF & (days) & (g.plant $\left.{ }^{-1}\right)$ & $(\%)$ & (g.plant ${ }^{-1}$ ) \\
\hline Treatments & 62 & $308.79 * *$ & $4213.49 * *$ & $3.21 * *$ & $92.64 * *$ \\
\hline Groups (G1 vs G2) & 1 & $27.43 * *$ & $756.00 * *$ & $38.19 * *$ & $108.77 * *$ \\
\hline GCA - Group 1 & 6 & $2512.31 * *$ & $31119.17 * *$ & $17.23 * *$ & $576.77 * *$ \\
\hline GCA - Group 2 & 6 & $487.97 * *$ & $7779.90 * *$ & $6.15^{* *}$ & $245.05 * *$ \\
\hline SCA & 49 & $22.78 * *$ & $552.78 * *$ & $0.42 * *$ & $14.37 * *$ \\
\hline Residue & 309 & 1.1 & 33.77 & 0.0545 & 1.71 \\
\hline
\end{tabular}

Notes:** significant at $1 \%$ probability, by the $\mathrm{F}$ test. 
The formation of base-populations from genetically superior parents from two groups was viable and should deliver satisfactory gains through the selection of individuals in segregating generations.

The GCA occurs mainly due to additive variance and additive $\mathrm{x}$ additive epistatic variance and the SCA results from the dominance genetic variance. This showed that for the expression of the evaluated traits, the additive, dominance and probably epistatic variances were important. According to Assman (1999), significant F values for GCA and SCA indicated the existence of variability due to additive and non-additive gene action, respectively.

In general, comparing Table 3 to Tables 5, 6, 7 and 8 , the order of the parents based on the means was similar to the order based on the estimated effects of GCA for all the traits. In other words, the per se development of the parents was indicative of their $\mathrm{g}_{\mathrm{i}}$ effects in such a way that when this association was true it was easier to correctly select the parents (Lopes et al. 2002). This corroborated breeder's practice of selecting parents with high means to cross.

In relation to the NDM trait, the parents with the highest $g_{i}$ effects were USP 14-07-05 (3) and USP 14-01-20 (2) for group 1 and A 7002 (13) and USP 70006 (8) for group 2. These parents contributed the most for obtaining late maturity plants. Parent PI 520.733 (5) (group 1) and USP 70004 (10) and USP 70109 (11) (group 2) contributed the most to early maturity and had a negative $g_{i}$ effect (Table $5)$.

Table 5 - Estimates of the effects of General Combing Ability (GCA) and Specific Combing Ability (SCA) using Griffing, method 2, adapted by Geraldi and Miranda Filho (1988), $\mathrm{F}_{2}$ generation, using hills, for number of days to maturity. 7 x 7 partial diallel. Soybean, ESALQ, Piracicaba-SP, year 2008/2009.

\begin{tabular}{|c|c|c|c|c|c|c|c|c|c|}
\hline $\mathbf{G}_{1} \backslash \mathbf{G}_{2}$ & $\begin{array}{c}\text { USP } \\
70006\end{array}$ & $\begin{array}{c}\text { USP } \\
70057\end{array}$ & $\begin{array}{c}\text { USP } \\
70004\end{array}$ & $\begin{array}{c}\text { USP } \\
\mathbf{7 0 1 0 9}\end{array}$ & $\begin{array}{c}\text { USP } \\
\mathbf{7 0 0 8 0}\end{array}$ & A 7002 & $\begin{array}{c}\text { USP } \\
70123 \\
\end{array}$ & \multirow[b]{2}{*}{$\mathbf{S}_{\mathrm{ji}}$} & \multirow{2}{*}{$\begin{array}{c}\text { GCA effect } \\
\left(\mathrm{gi}_{1}\right)\end{array}$} \\
\hline \multicolumn{8}{|c|}{ SCA effect $\left(s_{i j}\right)$} & & \\
\hline USP 14-10-38 & 1.03 & -2.15 & 2.12 & 0.39 & 0.3 & 0.67 & 0.85 & -1.61 & 2.21 \\
\hline USP 14-01-20 & 1.39 & -0.79 & 0.48 & -2.24 & -0.33 & -1.97 & 1.21 & 1.12 & 2.84 \\
\hline USP 14-07-05 & -0.52 & -0.7 & 0.58 & -0.15 & -0.24 & -1.88 & 2.3 & 0.30 & 3.75 \\
\hline USP 14-13-16 & 0.76 & 2.58 & 2.85 & -2.88 & -1.97 & 0.39 & 1.58 & -1.15 & 2.48 \\
\hline PI 520.733 & -0.97 & -0.15 & 1.12 & 2.39 & -0.7 & -2.33 & -4.15 & 2.39 & -13.79 \\
\hline IAC 100 & 1.94 & -0.24 & 1.03 & 1.3 & -0.79 & -0.42 & 0.76 & -1.79 & 0.3 \\
\hline M-SOY 8001 & -2.97 & 3.85 & 2.12 & 0.39 & -0.7 & 1.67 & -1.15 & -1.61 & 2.21 \\
\hline $\mathbf{S}_{\mathrm{ii}}$ & -0.33 & -0.7 & -5.15 & 0.39 & 2.12 & 1.94 & -0.7 & & \\
\hline GCA effect $\left(\mathrm{gi}_{2}\right)$ & 2.14 & -1.68 & -2.95 & -2.22 & -1.13 & 4.51 & 1.32 & & \\
\hline S.D. $\left(s_{i i}\right)=$ & 0.36 & & & & & & & & \\
\hline S.D. $\left(s_{i j}\right)=$ & 0.42 & & & & & & & & \\
\hline S.D. $($ gi) $=$ & 0.12 & & & & & & & & \\
\hline
\end{tabular}

For the GY trait, the GCA data (Table 6) corroborated the data obtained from the means (Table 3), because the two highest values of GCA, USP 14-01-20 (2) and USP 70080 (12) were also the highest means in the Scott-Knott test. In group 1 , the extreme negative effect of PI in the trait stood out, indicating that this genotype had fewer adapted alleles than the other parents. On the other hand, IAC 100 was the only other parent in the group with a negative effect, mainly due to its insect resistance and not productive performance. In group 2, USP 70080 (12) was the most promising parent because it presented the highest concentration of favorable alleles for grain yield. In relation to the $\mathrm{OC}$ trait (Table 7 ), the parents with the highest $g_{i}$ effects were USP 14-01-20 (2) and USP 14-07-05 (3) for group 1 and A 7002 (13) and USP 70109 (11) for group 2. The parents IAC 100 (6) and PI 520.733 (5) (group 1) and USP 70006 (8) and USP 70123 (14) (group 2) had the lowest amount of favorable alleles for oil content in the seeds, presenting negative $\mathrm{g}_{\mathrm{i}}$ effects.

For the OY trait (Table 8), the parent that contributed the most for obtaining high oil yield and that had the highest amount of favorable alleles (higher $g_{i}$ effects) were, respectively, in group 1, USP 14-01-20 (2), M-Soy 8001 (7) and USP 14-10-38 (1) and, in group 2, USP 70080 (12), followed by A 7002 (13). The parents that least contributed to oil yield were, respectively, PI 520.733 (5) and IAC 100 (6) (group 1), as well as USP 70057 (9) and USP 70004 (10) (group 2), presenting negative $g_{i}$ effects. 
Table 6 - Estimates of the effects of General Combing Ability (GCA) and Specific Combing Ability (SCA) using Griffing, method 2, adapted by Geraldi and Miranda Filho (1988), $\mathrm{F}_{2}$ generation, using hills, for grain yield $\left(\right.$ g plant $\left.^{-1}\right) .7$ x 7 partial diallel. Soybean, ESALQ, Piracicaba-SP, year 2008/2009.

\begin{tabular}{|c|c|c|c|c|c|c|c|c|c|}
\hline $\mathbf{G}_{1} \backslash \mathbf{G}_{2}$ & $\begin{array}{c}\text { USP } \\
\mathbf{7 0 0 0 6}\end{array}$ & $\begin{array}{c}\text { USP } \\
\mathbf{7 0 0 5 7}\end{array}$ & $\begin{array}{c}\text { USP } \\
70004\end{array}$ & $\begin{array}{c}\text { USP } \\
\mathbf{7 0 1 0 9}\end{array}$ & $\begin{array}{c}\text { USP } \\
\mathbf{7 0 0 8 0}\end{array}$ & A 7002 & $\begin{array}{c}\text { USP } \\
\mathbf{7 0 1 2 3} \\
\end{array}$ & \multirow[t]{2}{*}{$\mathbf{S}_{\mathrm{jj}}$} & \multirow[t]{2}{*}{ GCA effect $\left(\mathrm{gi}_{1}\right)$} \\
\hline & \multicolumn{7}{|c|}{ SCA effect $\left(s_{i j}\right)$} & & \\
\hline USP 14-10-38 & -5.09 & 9.36 & 6.82 & 10.09 & 1.09 & 5.27 & 0.45 & -19.0 & 8.29 \\
\hline USP 14-01-20 & 0.82 & -6.73 & -2.27 & 11.00 & 11.00 & 3.18 & -2.64 & -7.18 & 19.38 \\
\hline USP 14-07-05 & 7.00 & -3.55 & -1.09 & 15.18 & 4.18 & -7.64 & 13.55 & -13.83 & 10.19 \\
\hline USP 14-13-16 & 8.45 & 1.91 & -1.64 & -6.36 & -10.36 & 12.82 & 9.00 & -6.91 & 3.74 \\
\hline PI 520.733 & -8.91 & -3.45 & -4.00 & 8.27 & 2.27 & 18.45 & -11.36 & -0.64 & -46.90 \\
\hline IAC 100 & -1.27 & 1.18 & -7.36 & -6.09 & -10.09 & 11.09 & -6.73 & 9.64 & -2.53 \\
\hline M-SOY 8001 & 3.36 & -2.18 & 10.27 & -6.45 & -4.45 & 5.73 & -4.09 & -1.09 & 7.83 \\
\hline $\mathbf{S}_{\mathrm{ii}}$ & -2.18 & 1.73 & -0.36 & -12.82 & -1.82 & -24.45 & 0.91 & & \\
\hline GCA effect (gi) & -2.62 & -16.08 & -7.53 & -1.80 & 18.19 & 6.01 & 3.83 & & \\
\hline S.D. $\left(s_{i i}\right)=$ & 2.02 & & & & & & & & \\
\hline S.D. $\left(s_{i j}\right)=$ & 2.37 & & & & & & & & \\
\hline S.D. (gi) = & 0.73 & & & & & & & & \\
\hline
\end{tabular}

Table 7 - Estimates of the effects of General Combing Ability (GCA) and Specific Combing Ability (SCA) using Griffing, method 2, adapted by Geraldi and Miranda Filho (1988), $\mathrm{F}_{2}$ generation, using hills, for oil content (\%). $7 \mathrm{x}$ 7 partial diallel. Soybean, ESALQ, Piracicaba-SP, year 2008/2009.

\begin{tabular}{|c|c|c|c|c|c|c|c|c|c|}
\hline $\mathbf{G}_{1} \backslash \mathbf{G}_{2}$ & $\begin{array}{c}\text { USP } \\
70006\end{array}$ & $\begin{array}{c}\text { USP } \\
70057\end{array}$ & $\begin{array}{c}\text { USP } \\
70004\end{array}$ & $\begin{array}{c}\text { USP } \\
70109\end{array}$ & $\begin{array}{c}\text { USP } \\
70080\end{array}$ & A 7002 & $\begin{array}{c}\text { USP } \\
70123\end{array}$ & & \\
\hline & \multicolumn{7}{|c|}{ SCA effect $\left(s_{i j}\right)$} & $\mathbf{S}_{\mathrm{ii}}$ & GCA effect $\left(\mathrm{gi}_{1}\right)$ \\
\hline USP 14-10-38 & -0.24 & 0.49 & -0.12 & -0.21 & 0.09 & -0.23 & -0.07 & 0.14 & 0.25 \\
\hline USP 14-01-20 & 0.28 & -0.07 & -0.17 & -0.15 & 0.07 & -0.36 & -0.16 & 0.28 & 0.55 \\
\hline USP 14-07-05 & -0.7 & 0.12 & -0.2 & -0.13 & 0.61 & -0.12 & 0.25 & 0.08 & 0.54 \\
\hline USP 14-13-16 & 0.17 & -0.26 & -0.21 & -0.14 & 0.1 & -0.11 & 0.26 & 0.1 & 0.35 \\
\hline PI 520.733 & -0.3 & 0.63 & 0.2 & 0.78 & 0.25 & 0.8 & -0.66 & -0.86 & -0.81 \\
\hline IAC 100 & -0.4 & -0.14 & -0.24 & 0.17 & -0.32 & -0.07 & 0.26 & 0.34 & -1.25 \\
\hline M-SOY 8001 & 0.13 & -0.64 & 0.04 & -0.27 & -0.07 & -0.04 & 0.03 & 0.41 & 0.37 \\
\hline $\mathrm{S}_{\mathrm{ii}}$ & 0.52 & -0.06 & 0.35 & -0.025 & -0.37 & 0.04 & 0.04 & & \\
\hline GCA effect (gi $)$ & -0.41 & -0.09 & 0.03 & 0.03 & -0.08 & 0.91 & -0.34 & & \\
\hline S.D. $\left(s_{i i}\right)=$ & 0.15 & & & & & & & & \\
\hline S.D. $\left(s_{i j}\right)=$ & 0.17 & & & & & & & & \\
\hline S.D. $($ gi) $=$ & 0.05 & & & & & & & & \\
\hline
\end{tabular}

Table 8 - Estimates of the effects of General Combing Ability (GCA) and Specific Combing Ability (SCA) using Griffing, method 2, adapted by Geraldi and Miranda Filho (1988), $\mathrm{F}_{2}$ generation, using hills, for oil yield (g.plant ${ }^{-1}$ ). 7 x 7 partial diallel. Soybean, ESALQ, Piracicaba-SP, year 2008/2009.

\begin{tabular}{|c|c|c|c|c|c|c|c|c|c|}
\hline $\mathbf{G}_{1} \backslash \mathbf{G}_{2}$ & $\begin{array}{c}\text { USP } \\
70006\end{array}$ & $\begin{array}{c}\text { USP } \\
70057\end{array}$ & $\begin{array}{c}\text { USP } \\
70004\end{array}$ & $\begin{array}{c}\text { USP } \\
70109\end{array}$ & $\begin{array}{c}\text { USP } \\
70080\end{array}$ & $\begin{array}{c}\text { A } \\
7002\end{array}$ & $\begin{array}{c}\text { USP } \\
70123\end{array}$ & \multirow[b]{2}{*}{$\mathbf{S}_{\mathrm{iij}}$} & \multirow{2}{*}{$\begin{array}{c}\text { GCA effect } \\
\left(\mathbf{g i}_{1}\right)\end{array}$} \\
\hline & \multicolumn{7}{|c|}{ SCA effect $\left(s_{i j}\right)$} & & \\
\hline USP 14-10-38 & -2.65 & 1.97 & 1.85 & 1.17 & 3.8 & -0.21 & -1.56 & -2.18 & 1.47 \\
\hline USP 14-01-20 & -1.44 & -0.86 & -1.18 & 3.66 & 2.53 & -0.61 & -1.11 & -0.49 & 4.08 \\
\hline USP 14-07-05 & 1.3 & -0.1 & -3.68 & 1.77 & 1.36 & -2.45 & 2.46 & -0.33 & 1.58 \\
\hline USP 14-13-16 & 2.84 & -1.15 & -1.07 & -3.7 & -1.72 & 4.31 & 2.45 & -0.98 & 0.97 \\
\hline PI 520.733 & -1.01 & -1.7 & 1.58 & 2.27 & -0.94 & 4.1 & -2.39 & -0.95 & -8.64 \\
\hline IAC 100 & 0.71 & 0.43 & -1.03 & -1.37 & -1.44 & 2.21 & -0.33 & 0.41 & -1.72 \\
\hline M-SOY 8001 & 0.09 & -0.05 & 4.21 & -1.66 & -1.48 & -0.09 & -0.6 & -0.21 & 2.26 \\
\hline $\mathbf{s}_{\mathrm{ii}}$ & 0.08 & 0.73 & -0.34 & -1.07 & -1.05 & -3.63 & 0.54 & & \\
\hline GCA effect (gi $)$ & -1.57 & -3.92 & -1.39 & -0.53 & 4.15 & 2.62 & 0.63 & & \\
\hline S.D. $\left(s_{\mathrm{ii}}\right)=$ & 0.82 & & & & & & & & \\
\hline S.D. $\left(s_{i j}\right)=$ & 0.97 & & & & & & & & \\
\hline S.D. (gi) = & 0.3 & & & & & & & & \\
\hline
\end{tabular}

In general, the genotypes (not adapted to Brazilian conditions) such as PI 520.733 (5), when cultivated in intermediate latitudes, such as
Piracicaba (22 $\left.42^{\prime} 30^{\prime \prime}\right)$ tended to be early maturing and, consequently, grew less and had low agronomic performance for the grain and oil yield. 
Similar results were found by Lopes (2002). In this work, the exotic genotype was selected mainly as a source of resistance genes for $F$. solani f. sp. glycines. The parents USP 14-01-20 (2) and USP 14-07-05 (3) from group 1 and the parents A 7002 (13) and USP 70080 (12) from group 2 most contributed for obtaining the best individuals for the main traits evaluated such as grain yield, oil content and oil yield.

After identifying the superior parents, based on GCA, it was interesting to verify the estimates of the SCA to orient the development of biparental hybrid populations with the highest productive potential. The interpretation of the SCA effect is a deviation of the hybrid in relation to what would be expected based on the GCA of its parents. For the NDM trait, the crosses that demonstrated dominance tendencies for earliness were those with negative $\mathrm{s}_{\mathrm{ij}}$ estimates, standing out PI 520.733 (5) x USP 70123 (14), USP 14-13-16 (4) x USP 70109 (11), M-Soy 8001 (7) x USP 70006 (8) and PI 520.733 (5) x A 7002 (13). The crosses that presented the highest SCA effects for NDM were M-Soy 8001 (7) x USP 70057 (9), USP 14-13-16 (4) $x$ USP 70004 (10) and USP 14-07-05 (3) x USP 70123 (14). For the GY trait, the crosses with highest $\mathrm{s}_{\mathrm{ij}}$ estimates (better SCA) were, respectively, PI 520.733 (5) x A 7002 (13), USP 14-07-05 (3) x USP 70109 (11), USP 14-07-05 (3) $x$ USP 70123 (14) and USP 14-13-16 (4) x A 7002 (13). It was expected that the combination between USP 14-07-05 (3) and USP 70123 (14), as well as between USP 14-13-16 (4) and A 7002 (13) would result in a superior hybrid, because the parents showed high GCA estimate.

The combination PI 520.733 (5) x A 7002 (13) presented the highest estimate for SCA, indicating good complementarity of these parents. However, this did not guarantee a good combination if the mean of this cross was low, which was the case, as shown in Table 3. For this case, the occurrence of possible transgressive segregants was expected when this population was advanced to homozygosis and was constituted of a mixture of pure lines. For the success of a breeding program, the ideal would be to evaluate the lines extracted from this population in the presence of the pathogen to select more adapted and resistant lines, originated from the PI. If the adaptation was still not sufficient to release these lines as cultivars, the identification of lines more adapted than the original PI and that retained resistance to SDS could be crucial to a new cycle of crosses and extraction of highly adapted and resistant genotypes.

For the OC trait, the crosses that presented the highest $\mathrm{s}_{\mathrm{ij}}$ estimates were PI 520.733 (5) x USP 70109 (11) followed by PI 520.733 (5) x A 7002 (13) and PI 520.733 (5) x USP 70057 (9), showing that these crosses were better than expected based on the GCA, because the parent PI 520.733 (5) presented negative $g_{i}$ effect for OC. The crosses with the lowest $s_{i j}$ estimates were USP 14-07-05 (3) x USP 70006 (8), PI 520.733 (5) x USP 70123 (14) and M-Soy 8001 (7) x USP 70057 (9), respectively, indicating good complementarity with each other for the trait. For the OY trait, the crosses that presented the best $\mathrm{s}_{\mathrm{ij}}$ estimates (positive SCA), in other words, crosses with more variability, and that could generate high oil yield plants, were PI 520.733 (5) x A 7002 (13), USP 14-13-16 (4) x A 7002 (13) and USP 14-01-20 (2), respectively, while the crosses with the lowest estimates for $\mathrm{s}_{\mathrm{ij}}$ (worst SCA) were USP 14-13-16 (4) x USP 70109 (11), followed by USP 14-10-38 (1) x USP 70006 (8) and USP 14-07-05 (3) x USP 70004 (10).

Some crosses had parents with $\mathrm{g}_{\mathrm{i} \text { 's }}$ of opposite signs, whose combination resulted in a high $\mathrm{s}_{\mathrm{ij}}$, such as M-Soy 8001 (7) x USP 70004 (10) for GY; PI 520.733 (5) x USP 70109 (11) for OC; USP 14-01-20 (2) x USP 70109 (11) for OY, as well as PI 520.733 (5) x A 7002 (13) for these three traits. This fact was important because these combinations could generate transgressive segregants, if the additive effect of one parent and the epistatic effects complementary from the other parent acted in the same direction for the maximum expression of the traits (Sharma and Phul 1994).

In relation to the SCA of parent $\mathrm{i}$ with himself $\left(\mathrm{s}_{\mathrm{ii}}\right.$ and $s_{j j}$ ), these estimates had an important genetic meaning in sign and magnitude. A negative sign indicated the existence of positive dominance. The magnitude of $s_{\mathrm{ii}}$ was an indicator of genetic divergence of parent $i$ in relation to the group of the other parents being tested in the diallel. Therefore, the higher the $\mathrm{s}_{\mathrm{ii}}$ effect in absolute value the further the allelic frequency of parent $i$ would be from the mean allelic frequency of the parents and, consequently, the higher the divergence in relation to the others (Cruz and Regazzi 1997).

The parents USP 14-10-38 (1), PI 520.733 (5) and USP 70057 (9) had negative $s_{\mathrm{ii}}$, in other words, positive dominance for most traits evaluated, except for OC in USP 14-10-38 (1); for NDM in 
PI 520.733 (5), as well as for OY in USP 70057 (9). On the other hand, parents USP 14-01-20 (2), USP 14-07-05 (3), IAC 100 (6), USP 70080 (12) and USP 70123 (14) presented positive $\mathrm{s}_{\mathrm{ii}}$ for most traits evaluated, except for GY in USP 14-01-20 (2) and USP 14-07-05 (3); for NDM in IAC 100 (6) and USP 70123 (14) and for OY in USP 70080 (12). The most divergent parents, which presented positive dominance, in other words, with a highly negative $s_{\mathrm{ii}}$ were, respectively, USP 7004 (10) and IAC 100 (6) for the trait NDM; A 7002 (13) and USP 14-10-38 (1) for GY; PI 520.733 (5) and USP 70080 (12) for OC, as well as A 7002 (13) and PI 520.733 (5) for the OY trait. On the other hand, the least divergent parents with negative dominance (low and positive $\mathrm{s}_{\mathrm{ii}}$ ) for the traits NDM, GY, OC and OY were, respectively, USP 14-01-20 (2) and USP 14-07-05 (3); USP 70123 (14) and IAC 100 (6); USP 70123 (14) and A 7002 (13); USP 70109 (11) and USP 14-01-20 (2).

It would be important to highlight that although the most promising crosses had the possibility of generating the lines with good agronomic characteristics for the evaluated traits (NDM, GY, OC and OY), they should be still tested for their ability to combine these traits with SDS resistance and characterize them.

\section{CONCLUSION}

There was variability in the parents and progeny for all the traits evaluated. The additive and dominance genetic effects were both important. However, the additive variance was comparatively higher than the non-additive variance, indicating the possibility of obtaining transgressive segregants for the evaluated traits. The parent with the highest general combining ability and highest mean for oil content was the cultivar A 7002. The lowest values were found in PI 520733 and IAC 100. The crosses with the highest oil yields were those that involved parent A 7002, except when it was crossed with IAC 100.

\section{REFERENCES}

Assmann IC. Diversidade genética e análise dialélica em trigo (Triticum aestivum L.) [Tese]. Viçosa, Brasil: Universidade Federal de Viçosa; 1999.

Brieu TP, Parente V. Programa nacional de produção de biodiesel: um balanço da primeira fase até 2008. Rev Bio BR. 2009; 2(12): 62-64.
Cruz CD, Regazzi AJ. Modelos biométricos aplicados ao melhoramento genético. 2nd ed. Viçosa: UFV; 1997.

Cruz CD. Programa Genes: Biometria. 1st ed. Viçosa: UFV; 2006.

Farias Neto JT, Vello NA. Avaliação de progênies $\mathrm{F}_{4: 3}$ e $\mathrm{F}_{5: 3}$ e estimativas de parâmetros genéticos com ênfase para porcentagem de óleo, produtividade de grãos e óleo em soja. Ciênc Agrotec. 2001; 25: 812-820.

Federer, WT. Augment designs. Haw Plant Rec. 1956; 55 : 191-208.

Fronza V, Vello NA, Camargo, LEA. Genetic analysis of soybean resistance to Fusarium solani f. sp. glycines. Genet Mol Biol. 2004; 27(3): 400-408.

Geraldi IO, Miranda Filho JB. Adapted models for the analysis of combining ability of varieties in partial diallel crosses. Braz J Genet. 1988; 11(2): 419-430.

Griffing B. Concept of general and specific combining ability in relation to diallel crossing systems. Austr $J$ Biol Sci. 1956; 9: 463-493.

Lopes ACA, Vello NA, Pandini F, Rocha MM, Tsutsumi CY. Variabilidade e correlações entre caracteres em cruzamentos de soja. Sci Agric. 2002; 59(2): 341-348.

Miranda MAC, Suassuna Filho J, Bulisani EA, Mascarenhas HAA, Tisseli Filho O, Braga NR. Efeito maternal e do genótipo sobre o teor de óleo e tamanho de sementes em sementes $F_{1}$ de soja. In: III Seminário Nacional de Pesquisa de Soja: Anais do III Seminário Nacional de Pesquisa de Soja; 1984; Londrina, Brasil. Londrina: Embrapa-CNPS; 1984. p. 308-317.

Pimentel Gomes F. Análise conjunta de experimentos em blocos ao acaso com alguns tratamentos comuns. In: Pimentel Gomes F, editor. Curso de estatística experimental. Piracicaba: Degaspari; 2000. p. 330-347.

Ramalho MAP, Ferreira DF, Oliveira AC. Experimentação em genética e melhoramento de plantas. 2. ed. Lavras: UFLA, 2005, $322 \mathrm{p}$.

Sas Institute. SAS System: SAS/STAT. 8th ed. Cary; 1999.

Scott AJ, Knott MA. Cluster analysis method for grouping means in the analysis of variance. Biometrics. 1974; 30: 507-512.

Sharma SK, Phul PS. Combining ability analysis in soybean. Indian J Genet Plant Breed. 1994; 54(3): 281286.

Sudaric A, Vrtaric M, Sudar R, Duvnjak T, Jurkovic G. Breeding soybean for improved oil quantity and quality. In: IV Central European Congress of Food: Proceedings IV Central European Congress of Food; 2008; Cavta, Croatia. Cavta; 2008. p. 149-154.

Vello NA. Ampliação da base genética do germoplasma e melhoramento da soja na ESALQ/USP. In: I Simpósio Sobre a Cultura e Produtividade da Soja: Anais do I Simpósio Sobre a Cultura e Produtividade da Soja; 1991; Piracicaba, Brasil. Piracicaba: Fealq; 1992. p. 6081.

Vieira PFMJ. Dialelo entre genitores de soja tolerantes à ferrugem asiática [Tese]. Piracicaba, Brasil: Universidade de São Paulo; 2009. Accepted: November 04, 2013. 